\title{
Pandemi Koşullarında e-Ticarete Doğru Kurumsal Dönüşüm Sürecinde Kriz Yönetiminin İşlevselliğinin Analizi: Bir Ulusal Zincirde Örgütsel Güçlenme Üzerindeki Yansımalar
}

\author{
Keziban TALAK, Medeniyet Üniversitesi, Öğr. Gör. Dr., keziban.talak@medeniyet.edu.tr, \\ (D) 0000-0002-7837-5852
}

$\ddot{O Z Z}$

Covid-19, Mart 2020'den bu yana tüm dünyayı en üst düzeyde olumsuz etkileyen ve tüm yaşamı kuşatan, birkaç sektör dışında neredeyse tüm sektörlerde yıkıcı etki yapan büyük ve daha önce görülmemiş bir kriz durumudur. Söz konusu virüs doğrudan doğruya insan să̆hlğ̆ın tehdit ettiğinden, küresel çapta insan yaşamıyla ilgili olarak kurulan bütün sosyal ve ekonomik süreçlerin durmasına ve hem üretim hem de tüketim sistemlerinin çökmesine neden olmuştur. Bu durumun örgütsel sağhl̆ğ ve örgütsel performansı etkilememesi mümkün değildir. Bu bă̆lamda, örgütlerin, ellerindeki çeşitli enstrümanlarla müdahale ve önlemleri söz konusu olmaktadır. İsletmelerin tepe yönetimlerinin sahip olduğu kriz yönetimi anlayışı bu kapsamda yer almaktadır. Tepe yönetimlerinin müdahale ve önlemlerinin en net görülebildiği alanlardan biri de e-ticaret süreçlerine yönelik olarak yapılan örgütsel dönüşüm çabalarıdır. Kriz koşullarının neden olduğ u makro değişiklikler bir yandan örgütün yapısında ve diğer yanda da iş yapma biçimlerinde önemli değişiklikler yapılmasını gerektirebilmektedir. Günümüzde ulaşılan teknolojik seviye ile iletişimin artık bir etkileşim olarak farklı bir formata geçiş yaptiğı görülmektedir. Sadece örgütlerde değil, ayn zamanda devletler bazında, bireylerde ve dünyadaki tüm süreçlerde internete dayal dönüşüm yaşanmaktadır. Bu teknolojinin ve yeni anlayışların, yeni yaşam tarzlarmın dikkate alınarak örgütsel faaliyetlerin güncellenmesi bir zorunluluktur. Bu bağlamda e-ticaret tüm örgütler için bir yenilik, bir firsat ve bir güncelleme anlamına gelmektedir. Bununla birlikte, örgütlerin kendi geleneksel süreçlerini terk ederek e-ticarete doğru yoğunlaşmaları ya da geleneksel faaliyetlerin yanına eticaret süreçlerini entegre etmeleri örgüt içinde çeşitli problemleri de beraberinde getirme riskini taşımaktadır. Eski ve geleneksel süreçlerin terk edilmesi kıdemli personelde bir tedirginlik ve hoşnutsuzluk kaynă̆ına dönüşebilmektedir. Yeni iş akışlarının ortaya çıkması ile yeni vasıflarm gerekliliği gündeme gelmektedir. Bununla birlikte örgüt daha nitelikli personel istihdamına yönelebilmektedir. Eski/kıdemli çalışanlara örgüt içi eğitimler verilse bile söz konusu çalışanlarm yeni vasıfları elde edememe riski önemli bir risk durumundadır. Bunlara ek olarak bazı departmanlarm ve pozisyonların kalıcı olarak ortadan kalkma ihtimali örgüt kamuoyu tarafindan algılanabilmektedir. Bu çerçevede, örgütün geleneksel faaliyetlerden e-ticarete geçiş yapması, e-ticarete yönelik istekliliği ve yoğunlaşma düzeyi, çalışanlar arasında "yenilik ve belirsizlikten kaynaklı" huzursuzluk yaratma potansiyeli taşımaktadır. Söz konusu huzursuzluğun örgüt boyunca yayılması durumunda ise kurumsal huzursuzluk olgusundan söz etmek mümkün olacaktır. Bu durumda örgütsel bağhlĭğın azalması, örgütsel yapıya ve kurumsal markaya yönelik muhtemel hasarlar önemli bir risk olarak ortaya çıkmaktadır. Problemli alanlara üst yönetim tarafından yapılacak müdahalelerin etkili olmaması durumunda ise iç faktörler kaynaklı örgüt-içi kriz ortamı oluşması söz konusu olabilecektir. Bu çalışmanın temel amacı, örgütlerin tepe yönetiminin sahip olduğu kriz yönetimi anlayışının örgütsel süreçlerde ve özellikle de bir nihai hedef olan örgütsel güçlenme üzerinde etkili olup olmadığını analiz etmektir. Bu bă̆lamda, araştırma kapsamındaki başlıca bağımsız değişken olan "tepe yönetimin kriz yönetimi anlayışı" ile bă̆ımlı değişken olarak belirlenen "örgütsel güçlenme" arasındaki ilişkiler incelenmektedir. Bu çalışmada kullanılan veriler bir ulusal zincirde franchise mağazalar olarak yer alan 133 işletmeden anket 
uygulaması yoluyla sağlanmıştır. Franchise zincirinin Türkiye Merkez ofisi "tepe yönetim" olarak ele alınmış ve franchise mağazalar da örgüt-içi birimler şeklinde düşünülmüştür. Araştırma modeline dayalı olarak çeşitli hipotezler test edilmiştir. Yapılan analizlerin sonucunda, tepe yönetimin kriz yönetimi anlayışının boyutları ile örgütsel güçlenme arasında anlamlı ve pozitif yönlü ilişkiler ortaya çıkmıştır. Diğer bir ifade ile, tepe yönetimin sahip olduğu kriz yönetimi anlayışının uzantısı olan yönetsel düzenlemeler ve uygulamalar örgütsel güçlenme üzerinde belirleyici olmaktadır.

Anahtar

: Kriz Yönetimi, Örgütsel Güçlenme, Örgütsel Liderlik, Örgütsel İletişim

Kelimeler

\section{An Analysis of the Functionality of Crisis Management Perspective of Top Management in Changing Traditional Processes to e-Commerce: Evidence from Organizational Resilience}

ABSTRACT
Since the virus in question directly threatens human health, it has caused the halt of all social and economic processes established in relation to human life on a global scale and the collapse of both production and consumption systems. It is not possible that this situation does not affect organizational health and organizational performance. In this context, organizations' interventions and precautions with various instruments at their disposal come into question. The crisis management understanding of the top management of businesses is included in this scope. One of the areas where top management's interventions and measures can be seen most clearly is the organizational transformation efforts towards e-commerce processes. Macro changes caused by the conditions of the crisis may require significant changes in the structure of the organization on the one hand and the way of doing business on the other. With the technological level reached today, it is seen that communication is now transitioning to a different format as an interaction. Internet-based transformation is taking place not only in organizations, but also on the basis of states, individuals and all processes in the world. It is a necessity to update organizational activities by taking into account this technology, new understandings and new lifestyles. In this context, e-commerce means an innovation, an opportunity and an update for all organizations. On the other hand, organizations abandoning their traditional processes and focusing on e-commerce or integrating e-commerce processes alongside traditional activities carry the risk of bringing along various problems within the organization. The abandonment of old and traditional processes can become a source of anxiety and discontent in senior staff. With the emergence of new workflows, the necessity of new qualifications comes to the fore. However, the organization can tend to employ more qualified personnel. Even if former / senior employees are provided with in-house training, the risk of these employees not obtaining new qualifications is a significant risk. In addition to these, the possibility of permanent disappearance of some departments and positions can be perceived by the organization public. In this framework, the organization's transition from traditional activities to e-commerce, its enthusiasm and concentration level towards e-commerce has the potential to create unrest among employees due to "innovation and uncertainty". If this unrest spreads throughout the organization, it will be possible to talk about the phenomenon of institutional unrest. In this case, the decrease in organizational commitment and possible damages to the organizational structure and corporate brand emerges as an important risk. If the interventions to be made by the senior management in problematic areas are not effective, it may be possible to create an internal crisis environment due to internal factors. The purpose of this study is to understand the relationship between top management's perspective on 'Crisis Management' and organizational resilience at the end of the process. The leading question of this study is to ask whether Managerial activities stemming from the perspective of top management towards crisis management is effective or not on organizational resilience 


\title{
Keywords : Crisis Management, Organizational Resilience, Organizational Leadership, Organizational Communication
}

\begin{abstract}
in a turbulent environment suffering from Covid - 19 effects. The data for this study was collected from 133 franchising stores who were 'the member units' in a national chain-stores brand. The data of this study was analyzed by employing some regression models based on a research model. The findings show that the perspective of top management towards crisis management has meaningful and positive effects on organizational resilience. In other words, organizational resilience under crisis conditions can be explained by the factors of crisis management understanding of top management.
\end{abstract}

\section{EXTENDED ABSTRACT}

Covid 19 represents an unprecedented crisis that has had a devastating impact on many industries since March 2020. Since the virus directly threatens human health, it has caused the halt of all social and economic processes established for human life on a global scale and the collapse of both production and consumption systems. It can be stated that the new conditions can play an important negative role towards organizational health and performance. Therefore, organizations as market players need to intervene in this potential problem with a variety of instruments.

In this context, the understanding of crisis management of organizations can be a leading instrument that can be employed in this global and severe crisis. The efforts for organizational transformation towards the processes in e-commerce and e-business represent one of the areas where top management's interventions and measures can be seen most clearly. Macro changes caused by global crisis may require significant changes in the organization's structure and the ways of doing business. On the other hand, today's internet technology and unlimited communication possibilities based on the internet also require the updates of market activities and organizational processes. Thus, the area of e-commerce and e-business means an innovation, an opportunity and an update for all organizations.

However, previous academic studies showed that organizations have faced some important problems in their internal environment when they abandon their traditional processes and focus intensively on e-commerce. The abandonment of old and traditional processes can become a source of anxiety and discontent in senior members of the organization. For instance, new qualifications needed in the organization can be mentioned by management with the emergence of new workflows based on new technology and internet. Obviously, organizations can tend to employ more qualified personnel. Even if senior employees are provided with in-house trainings, the risk of these employees not acquiring new skills represents a significant risk. In addition, employees see the possibility of some departments and positions to disappear permanently. 


\section{AJIT-e Bilişim Teknolojileri Online Dergisi \\ Academic Journal of Information Tecnology}

2021 Spring/Bahar - Cilt/Vol: 12 - Sayı/Issue: 45

doi) 10.5824/ajite.2021.02.007.x

In this framework, the organization's transition from traditional activities to modern ways of doing business, its willingness and concentration level towards e-commerce and ebusiness obviously carry the potential for restlessness in the side of employees. It might be possible to talk about the phenomenon of organizational unrest If the unrest of some employees spreads throughout the organization. Thus, the risk of decreasing in organizational loyalty and also possible damages to the organizational structure and corporate brand can appear as an important risk for management. It is possible to state that an organizational crisis based on internal factors can be faced if the interventions made by top management in problem areas are not effective.

\section{Research Problem}

The research problem of this study can be stated with a fundamental question about the relationship between top management's crisis management approach and organizational resilience. The leading question or research problem of this study is as follow:

Does crisis management approach of top management affect the resilience of the organization at the end of the process stemming from the approach?

This specific research problem is examined in this study through a process including factors that are supposed to emerge as a natural extension of crisis management approach of top management. In this study, therefore, the research problem is discussed in the context of the interaction of some certain factors representing the variables of the study.

\section{Aim of the Study}

The aim of this study is to analyze the effect of crisis management approach of top management on organizational processes and especially in organizational strength as a final objective. To this aim, the relations between "crisis management approach of top management" as a fundamental independent variable of this study and the final dependent variable "organizational resilience" were analyzed through a research model developed for this study. The research model includes 6 variables and 8 hypothetical paths among them in the context of the specific aim of this study.

This study also aims to understand the reflections of top management's crisis management approach on some specific management activities such as communication, reorganization, leadership, and motivation. Therefore, the fundamental dependent variable "organizational resilience" is analyzed through these variables stemming from the approach of top management. 


\section{Methodology}

This study was conducted on 133 respondents who were operating as the members of a franchising chain in Turkey during January 2021. The head office of this franchising chain was considered as "top management" and franchisee stores as units of the organization. A set of hypotheses was developed and tested based on a research model of the study. The required data within this study is primary data. Therefore, the survey method which is one of the most functional ones in social sciences was employed to collect the data needed. The data collection process was carried out through face-to-face interviews. A questionnaire with 6 parts and 57 questions covering the variables in the research model of this study was developed for data collection process. A total of 57 expressions in the questionnaire form were presented with a 5-point Likert scale ranging from "strongly agree" to "strongly disagree".

\section{Findings}

The data obtained from survey through the questionnaire was analyzed by employing "principle component factor analysis" and regression models. Factor analysis indicated that top management's approach to crisis management can be considered in three sub-topic such as perceptional capacity, response speed or agility, and being restorative. As a result of the analyses, significant and positive relations have emerged between the dimensions of the crisis management understanding of top management and organizational resilience. All hypotheses developed in this study were confirmed statistically. The results of regression models showed that management operations as an extension of the crisis management approach of top management are significant determinants on organizational strength. Therefore, it is possible to state that in order to build organizational strength in crisis conditions directly depends on the variables of organizational communication, top management's leadership, reorganization activities, and motivation process designed by top management.

\section{GíRiş}

Örgütlerin faaliyette bulunduğu çevrenin en temel tanımlayıcı kavramı dinamizmdir. Örgütler faaliyetlerini sürekli değişmekte olan bir ortamda ve sürekli değişim gösteren muhataplara yönelik organize ederler. Bir anlamda dinamizm; durağanlık/stabilite durumunun tam tersini ifade etmektedir. Sürekli değişen bir ortamın varlığı ve muhatapların niteliklerinin sürekli değişmesi öngörülebilen ve öngörülemeyen problemlerin de sürekli gündemde olmasına neden olmaktadır. Bu bağlamda denilebilir ki örgütsel süreçler aslında problem çözme süreçleridir. Dolayısıyla, örgütsel süreçlerin tasarımı ve yönetimi problem çözme performansında belirleyici konumdadır.

Örgütsel süreçlerin işleyişi ve faaliyetlerin yürütülmesi sırasında yaşanan anlık veya kısa süreli problemlerin ötesinde, zamana yayılan, derinleşen ve büyük bir dış çevreden kaynaklanan problemler örgütsel yaşamı ve örgütün performansını tehdit eden faktörlerdir. 


\section{AJIT-e Bilişim Teknolojileri Online Dergisi \\ Academic Journal of Information Tecnology \\ 2021 Spring/Bahar - Cilt/Vol: 12 - Sayı/Issue: 45 \\ doi) 10.5824/ajite.2021.02.007.x}

Bunun yansıra, ayrıca bu problemlerin önceden öngörülemeyen biçimlerde ve tahmin edilemeyen zamanlamayla ortaya çımaları problemi daha da büyütmektedir. Zamana yayılan, tüm dış çevreyi kuşatan, tek başına örgütlerin çözmesi mümkün olmayan ve öngörülemeyen zamanlarda ortaya çıkan büyük sıkıntılar normal problemleri değil kriz durumlarını temsil etmektedir. Bu nitelikteki büyük problemlerin örgütün sağlığına ve örgütsel performansa yönelik muhtemel zararlarını minimize edebilmek örgüt yönetiminin ortaya koyacağı yönetim becerisi ve kapasitesi ile yakından ilişkilidir.

Covid-19, Mart 2020'den bu yana tüm dünyayı en üst düzeyde olumsuz etkileyen ve tüm yaşamı kuşatan, birkaç sektör dışında neredeyse tüm sektörlerde yıkıcı etki yapan büyük ve daha önce görülmemiş bir kriz durumudur. Söz konusu virüs doğrudan doğruya insan sağlığını tehdit ettiğinden, küresel çapta insan yaşamıyla ilgili olarak kurulan bütün sosyal ve ekonomik süreçlerin durmasına ve hem üretim hem de tüketim sistemlerinin çökmesine neden olmuştur. Bu durumun örgütsel sağlı̆̆1 ve örgütsel performansı etkilememesi mümkün değildir. Bu bağlamda, örgütlerin, ellerindeki çeşitli enstrümanlarla müdahale ve önlemleri söz konusu olmaktadır. İşletmelerin tepe yönetimlerinin sahip olduğu kriz yönetimi anlayışı bu kapsamda yer almaktadır. Tepe yönetimlerinin müdahale ve önlemlerinin en net görülebildiği alanlardan biri de e-ticaret süreçlerine yönelik olarak yapılan örgütsel dönüşüm çabalarıdır. Kriz koşullarının neden olduğu makro değişiklikler bir yandan örgütün yapısında ve diğer yanda da iş yapma biçimlerinde önemli değişiklikler yapılmasını gerektirebilmektedir. Geleneksel üretim ve satış süreçlerinin internet tabanlı yeni iletişim teknolojileriyle yer değiştirmesi aynı zamanda bir kurumsal dönüşüm anlamına da gelmektedir (Senior, 2002). İşletme içinde yaşanan böyle bir dönüşüm sürecinde eski anlayışlarla yeni anlayışların, eski vasıflar/gereklililer ile yeni vasıflar/gerekliliklerin örtülü ya da açık mücadelesi de sözkonusu olabilmektedir. Bu durumu iç çevre faktörlerinden kaynaklı bir iç-kriz olarak adlandırmak mümkündür (Kreitner ve Kinicki, 2003; Robbins, De Cenzo ve Coulter, 2014).

Tüm dünyayı kuşatan Pandemi koşullarının örgüte ve örgütsel performansa verebileceği zarar ile birlikte yukarıda sözü edilen iç-kriz bir araya geldiğinde hem dış çevre hem de iç çevrenin örgütün varlığına tehdit anlamında büyük bir toplam etki yaratma potansiyeli ortaya çıkmaktadır (Chapman, 2002). Sözkonusu potansiyel tehlike karşısında örgütün tepe yönetiminin “krizi ya da potansiyel krizi nasıl yönettiği, kısaca kriz yönetimini nasıl yaptığı ve ne tür sonuçlara neden olduğu sorusu önemli bir soru olarak gündeme gelmektedir. Buradan hareketle bu çalışma, tepe yönetimin sahip olduğu kriz yönetimi anlayışının sözkonusu sıkıntılı dönemlerde örgütün güçlenmesi üzerinde belirleyici olup olmadığını, diğer bir ifadeyle işlevselliğini incelemeye yöneliktir. 


\section{LİTERATÜR}

\subsection{Kurumsal Dönüşümün Bir Parçası Olarak e-Ticaret ve Kurumsal Riskler}

E-ticaret kavramını ve e-ticaret süreçlerini incelerken gözden kaçırılmaması gereken asıl odak noktası 1990'l1 yılların sonundan itibaren yaşanan internet tabanlı iletişim devrimidir. İnternet teknolojisinin tüm dünyada iletişim kavramını tamamen değiştirdiğini ve eski iletişim metotlarının neredeyse bütünüyle terk edildiğini söylemek mümkündür. Günümüzde ulaşılan teknolojik seviye ile iletişimin artık bir etkileşim olarak farklı bir formata geçiş yaptığı görülmektedir. Sadece örgütlerde değil, aynı zamanda devletler bazında, bireylerde ve dünyadaki tüm süreçlerde internete dayalı dönüşüm yaşanmaktadır. $\mathrm{Bu}$ teknolojinin ve yeni anlayışların, yeni yaşam tarzlarının dikkate alınarak örgütsel faaliyetlerin güncellenmesi bir zorunluluktur. Bu bağlamda e-ticaret tüm örgütler için bir yenilik, bir fırsat ve bir güncelleme anlamına gelmektedir. Bununla birlikte, örgütlerin kendi geleneksel süreçlerini terk ederek e-ticarete doğru yoğunlaşmaları ya da geleneksel faaliyetlerin yanına e-ticaret süreçlerini entegre etmeleri örgüt içinde çeşitli problemleri de beraberinde getirme riskini taşımaktadır (Kreitner ve Kinicki, 2003). Eski ve geleneksel süreçlerin terk edilmesi kıdemli personelde bir tedirginlik ve hoşnutsuzluk kaynağına dönüşebilmektedir (Zoogah ve Beugre, 2012). Yeni iş akışlarının ortaya çıkması ile yeni vasıfların gerekliliği gündeme gelmektedir. Bununla birlikte örgüt daha nitelikli personel istihdamina yönelebilmektedir. Eski/kıdemli çalışanlara örgüt içi eğitimler verilse bile sözkonusu çalışanların yeni vasıfları elde edememe riski önemli bir risk durumundadır (Bushe ve Marshak, 2009). Bunlara ek olarak bazı departmanların ve pozisyonların kalıcı olarak ortadan kalkma ihtimali örgüt kamuoyu tarafından algılanabilmektedir.

$\mathrm{Bu}$ çerçevede, örgütün geleneksel faaliyetlerden e-ticarete geçiş yapması, e-ticarete yönelik istekliliği ve yoğunlaşma düzeyi, çalışanlar arasında "yenilik ve belirsizlikten kaynaklı" huzursuzluk yaratma potansiyeli taşımaktadır. Söz konusu huzursuzluğun örgüt boyunca yayılması durumunda ise kurumsal huzursuzluk olgusundan söz etmek mümkün olacaktır (Kahn ve Barton, 2013). Bu durumda örgütsel bağlılığın azalması, örgütsel yapıya ve kurumsal markaya yönelik muhtemel hasarlar önemli bir risk olarak ortaya çıkmaktadır. Problemli alanlara üst yönetim tarafından yapılacak müdahalelerin etkili olmaması durumunda ise iç faktörler kaynaklı örgüt-içi kriz ortamı oluşması söz konusu olabilecektir.

\subsection{Kavramsal Olarak Kriz Yönetimi}

Kriz yönetimi kavramının içeriğini anlayabilmek için öncelikle krizin nasıl tanımlandığına bakılması gerekmektedir. Kriz kavramı, ürettiği sonuçların yaygın etkisi ve bozucu niteliği nedeniyle gerek işletme literatüründe gerek sosyal bilimlerin birçok alanında üzerinde yaygin olarak durulan kavramlardan biridir. Çevresel faktörlerde bir anda ortaya çıan negatif gelişmeler (Okumuş, 2003) kriz kavramını açıklarken kullanılan temel tarif 


\section{AJIT-e Bilişim Teknolojileri Online Dergisi \\ Academic Journal of Information Tecnology}

2021 Spring/Bahar - Cilt/Vol: 12 - Sayı/Issue: 45

doi) 10.5824/ajite.2021.02.007.x

biçimidir. Bu kısa tarifte, kriz kavramı ile ilgili birkaç önemli nokta birarada bulunmaktadır. Bunları; i) çevresel faktörlerde yani örgütlerin kontrol edemediği alanda meydana gelen değişmeler, ii) Bir anda ortaya çıkan yeni koşullar ve iii) Genel koşulların örgüt aleyhine olacak şekilde gelişmesi olarak ifade etmek mümkündür. Darling'e göre (1994) sözkonusu genel koşulların olumsuzluğu ve şiddeti/büyüklüğü nedeniyle hem örgütün yönetim kademelerinde hem de örgütün temel varlığı olan çalışanlar düzeyinde panikleme, korku ve moral çöküntüsü hızla baş göstermektedir. Dolayısıyla, kriz; örgütsel yapı üzerinde doğrudan bozucu etkiye (Farhoodi ve Babalhavaeji, 2015) sahip bir faktördür. Bu kritik etki potansiyelinden dolayı da seri bir şekilde tepki verilmesi ve önlemler geliştirilmesi gereken önemli bir tehlikedir (Dinçer, 1998: 384).

Kriz yönetimi kavramı da bu bağlamda ortaya çıkmış olan bir kavram durumundadır. Zira, gerekli önlemlerin geliştirilmesi ve hayata geçirilmesi bir sürecin gerekliliğini ortaya çıkarmaktadır. Diğer taraftan da sözkonusu sürecin yönetilmesi bir zorunluluk olmaktadır. Bu nedenle Garvare (2002) kriz yönetiminin aslında bir süreç yönetimi olarak tanımlanması gerektiğini ileri sürmektedir. Nitekim, sözkonusu süreç yönetimine işaret eden bir tanımlamada (Tüz, 2004: 84) kriz yönetimi; örgütsel yapıyı tehdit eden gelişmeler karşısında planlı ve sistematik olarak uygulanması gereken ve adım adım belirlenen önleyici müdahaleler topluluğu olarak ifade edilmektedir. Buna benzer bir yaklaşım OECD tarafından yayınlanan Stratejik Risk Yönetimi raporunda da kendini göstermektedir (OECD Risk Yönetimi Raporu, Baubion, 2013). Bu çalışmada da kriz yönetimi; bir yandan "hangi tekniklerin" geliştirilmesi gerektiğini konu edinen "Onset Management" ve diğer yandan da bu tekniklerin "nasıl uygulanması" gerektiğini ifade eden "response management" aşamaları olarak ele alınmaktadır.

Bu çerçevede kriz yönetimi esas itibariyle, çevresel faktörlerde ortaya çıkan ve örgütsel yapıyı en üst düzeyde tehdit eden ve aynı zamanda kısa süreli olmayıp bir zamana yayılan çalkantılı koşullarda yönetimin ortaya koyduğu yaklaşımlar ve davranışlardır. Penrose (2000, s.155) bu durumun en kritik aşamasını; tepe yönetimin tehlikeyi algılama kabiliyeti ve düzeyi olarak adlandırmaktadır. Bu durumun doğal uzantısı da algılamaya bağlı olarak tepe yönetimin hangi teknikler ve uygulamaları geliştirip geliştirmediğidir (Penrose, 2000, s.156). Diğer bir ifadeyle, örgütün üst yönetimi karşı karşıya kalınan krizi yönetebilmek için belli bir süreç boyunca çeşitli enstrümanlarla krize müdahil olma durumundadır. Bu enstrümanlar; üst yönetimin ortaya koyacağı liderlik performansı, tepe yönetimden tüm örgütsel kademelere yayılan iletişim, örgüt üyelerine yönelik motivasyon çalışmaları ve tüm süreçlerin yeni koşullara göre ele alınarak iyileştirilmesi (reorganizasyon) olarak ön plana çıkmaktadır (Gürgen, 1997; Myer, Conte ve Peterson, 2007; Hosseini, 2013; Starosta, 2014). 


\section{3. Örgütsel Liderlik, Örgütsel İletişim, Örgütsel Motivasyon, Reorganizasyon}

Kriz koşulları normal/rutin sıkıntıların olduğu dönemleri değil, tüm dış çevreyi kuştan derin ve süregiden olumsuz koşulları ifade etmektedir. Darling (1994); panik, korku ve moral çöküntüsünün ön plana çıtığı problemli dönemlerde örgüt üst yönetiminin sergileyeceği liderliğin aynı zamanda bir müdahale enstrümanı niteliğine dikkat çekmektedir. Zira üst yönetim tarafından ortaya konulacak liderlik performansı tüm örgüt boyunca çalışanların genel yaklaşımını, fiziksel ve ruhsal durumlarını etkileme potansiyeline sahiptir ( Drath ve Palus, 1994).

Bass'a göre (1990) liderlik; doğrudan doğruya "diğerlerinin" davranışlarını yönlendirmeye ve güdülemeye ilişkin olduğu için, herhangi bir olguya dair yönetim sürecinin de odak noktasını oluşturmaktadır. Bu bağlamda, örgütsel liderlik kavramını; üst yönetimin örgütün tüm kademelerine yönelttiği ve örgüt boyunca tüm kademelerin/departmanların algılamalarını ve davranışlarını canlı, pozitif ve üretken halde tutacak liderlik rolü olarak tanımlamak mümkündür (Trent, 2004). Bu yaklaşım, örgütün diğer bütün kademelerinde yer alan çalışanları görece olarak pasif konumlandırırken, üst yönetimin fonksiyonu ise olabildiğince aktiftir.

Daha önce de ifade edildiği gibi, üst yönetimin kriz koşullarında bir yönetim ve müdahale enstrümanı olarak kullanabileceği uygulamalardan biri de örgütsel iletişimdir. Örgütsel iletişim; örgütü oluşturan kişiler, gruplar ve kademeler/departmanlar arasında bilgi ve duygu akışının (Yılmaz, 2003) sağlandığı ve aynı zamanda tasarımının üst yönetim tarafından belirlendiği bir süreçtir (Sabuncuoğlu ve Tüz, 2005). Bilgi akışının, hangi bilgilerin ve hangi duyguları tetikleyecek bilgilerin, hangi zamanlamayla örgütün tüm kademeleri boyunca yayılacağı konuları üst yönetimin tercihlerine ve iletişim kavramına dair sahip olduğu algılamalara ve yaklaşıma bağlıdır. Örgüt boyunca üst yönetimin liderliğinde ve tercihleri doğrultusunda şekillenecek olan iletişim, tüm örgütte hangi bilgilerin ve hangi duyguların daha baskın olacağını da belirleyebilecek bir güce sahiptir (Taşlıyan ve Hırlak, 2014). Paylaşılan bilgiler, bilginin üst yönetim tarafından paylaşılma biçimleri ve özel olarak tetiklenen duyguların örgüt üyelerinde "örgüte bağl1lık" konusunda oldukça belirleyici olduğunu gösteren birçok çalışma bulunmaktadır (Frone ve Major, 1998; Rad ve Moares, 2009; Karcıoğlu ve diğerleri, 2009).

Özellikle kriz koşullarında örgütsel süreçlerin yönetimine dair yapılan akademik çalışmalar, üst yönetimin tüm örgütsel kademeler boyunca uyguladığı motivasyonel faaliyetlerin çalışanların psikolojsini canlı ve pozitif tuttuğu, bunun da sırasıyla bireysel performanslara ve örgütsel performansa yansıdığını ortaya koymaktadır (Tanrıverdi ve Oktay, 2001; Örücü ve Kanbur, 2008; Onay ve Ergüden, 2011). Bu bağlamda, üst yönetim 


\section{AJIT-e Bilişim Teknolojileri Online Dergisi \\ Academic Journal of Information Tecnology}

2021 Spring/Bahar - Cilt/Vol: 12 - Sayı/Issue: 45

doi) 10.5824/ajite.2021.02.007.x

tarafından planlanan, organize edilen, bilinçli olarak tercih edilen yöntemlerle yürütülen motivasyon faaliyetlerini kriz koşullarında baş gösteren panik, korku, olumsuz genel atmosfer ve moral çöküntüsü gibi tehditlerin kontrol edilmesinde fonksiyonel olan bir yönetim enstrümanı olarak tanımlamak mümkündür (Lee ve Raschke, 2016). Bununla birlikte birçok ampirik çalışma; çalışanlara yönelik bu tarz "onarıcı ve iyileştirici" uygulamaların örgütlerde tepe yönetimin kriz yönetimi kavramına bakış şeklinden ve diğer bir ifadeyle kriz yönetimi anlayışından kaynaklandığını belirtmektedir (Amabil ve Kramer, 2007; Rozman ve diğerleri, 2017; Madan, 2017).

Dış çevre koşullarında meydana gelen önemli değişiklikler ve bu değişimlerin örgüt içine yansıma biçimleri örgütün işleyişini ve örgütsel sağlı̆̆ tehdit edici bir nitelikle ortaya çıktığında örgütsel yapıda değişikliklere gitmek bir zorunluluk olabilmektedir. Böyle bir durumda örgütsel mimarinin ya da tasarımın değiştirilmesi ve güncellenmesi çabaları aynı zamanda işletmelerin açık sistemler olmasının da doğal bir uzantısıdır (Yüksel, 2016). Özellikle kriz koşullarında meydana gelen derin problemlerin işletmenin rekabet gücüne verdiği zararlar ve çalışanların daha etkili iç-operasyon süreçlerine duydukları ihtiyaçlar, örgütsel süreçlerin reorganizasyonunu gündeme getirmektedir. Reorganizasyon faaliyetlerine girişilirken üst yönetimin en temel motivasyonu; değişime ayak uydurabilmek, örgütsel modernizasyon ve sonuçta da örgütsel dinamizmi ve rekabet gücünü üst düzeye taşımaktır (Pira ve Kocabaş, 2003).

\section{MATERYAL VE YÖNTEM}

\section{1. Çalışmanın Amacı, Araştırma Modeli ve Hipotezler}

$\mathrm{Bu}$ çalışmanın amacı, pandemi sürecinin tetiklediği ve örgütler üzerinde tehditler oluşturan kriz koşullarında örgütlerdeki yönetimsel yaklaşımların somut sonuçlarını gözlemlemektir. Bu bağlamda örgütsel yapıyı ve örgütsel performansı etkileyebilecek birçok yaklaşım inceleme konusu yapılabilecektir. Bu çalışma kapsamında, kaotik koşullarda gündeme gelebilecek çeşitli yönetimsel yaklaşımlardan biri olan kriz yönetimi (KY) yaklaşımının tepe yönetim tarafından uygulanmasının fonksiyonel sonuçları incelenmektedir. Diğer bir ifadeyle, tepe yönetiminin sahip olduğu kriz yönetimi anlayışının örgütsel yapıda işlevsel sonuçlara neden olup olmadığı ele alınmaktadır.

Buradan hareketle bu çalışma; örgütlerdeki tepe yönetimin kriz yönetimi anlayışından (TYKYA) kaynaklanan yönetimsel uygulamaların örgütsel güçlenme (ÖG) üzerindeki yansımalarını incelemeye yöneliktir. Bu inceleme sadece TYKYA ve ÖG arasındaki doğrudan ilişkiyi değil, aynı zamanda bu iki değişken arasındaki ilişkide sözkonusu olabilecek çeşitli varsayımsal yapıları da içermektedir. Bu doğrultuda geliştirilen araştırma modeli ve hipotetik patikalar şekil 1'de sunulmaktadır. 


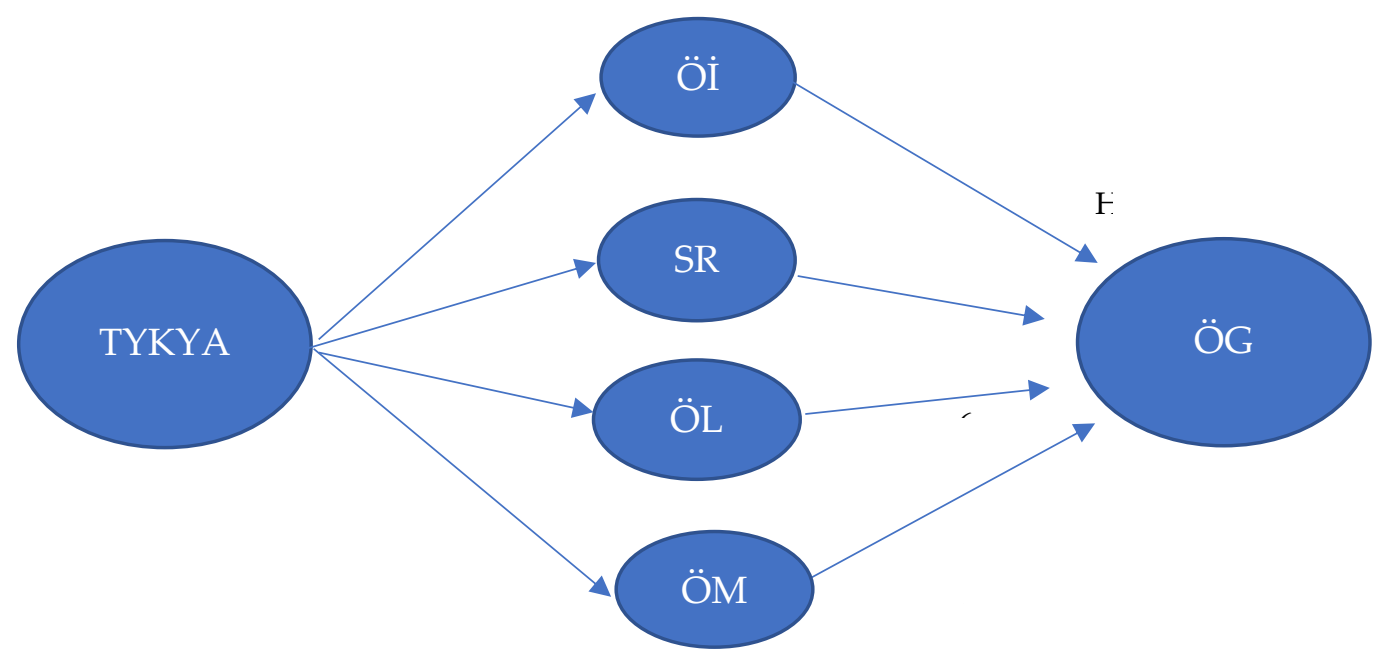

Şekil 1: Araştırma Modeli

TYKYA: Tepe Yönetimin Kriz Yönetimi Anlayışı, Öİ: Örgütsel İletişim, SR: Süreç Reorganizasyonu, ÖL: Örgütsel Liderlik, ÖM: Örgütsel Motivasyon, ÖG: Örgütsel Güçlenme Yukarıdaki araştırma modelinden hareketle, bu çalışmanın hipotezlerini şu şekilde ifade etmek mümkündür:

H1: Tepe yönetimin kriz yönetimi anlayışına sahipliği ile zincir mağazalara yönelik örgütsel iletişim faaliyetleri arasında istatistiksel olarak anlamlı bir ilişki vardır.

H2: Tepe yönetimin kriz yönetimi anlayışına sahipliği ile zincir mağaza süreçlerinin reorganizasyonu arasında istatistiksel olarak anlamlı bir ilişki vardır.

H3: Tepe yönetimin kriz yönetimi anlayışına sahipliği ile zincir mağazalara örgütsel liderlik yapması arasında istatistiksel olarak anlamlı bir ilişki vardır.

H4: Tepe yönetimin kriz yönetimi anlayışına sahipliği ile çalışanlara yönelik örgütsel motivasyon arasında istatistiksel olarak anlamlı bir ilişki vardır.

H5: Tepe yönetimin örgütsel iletişim uygulamaları ile zincir mağazaların örgütsel güçlenmeleri arasında istatistiksel olarak anlamlı bir ilişki vardır.

H6: Tepe yönetimin süreçlerin reorganizasyonu uygulamaları ile zincir mağazaların örgütsel güçlenmeleri arasında istatistiksel olarak anlamlı bir ilişki vardır.

H7: Tepe yönetimin örgütsel liderlik uygulamaları ile zincir mağazaların örgütsel güçlenmeleri arasında istatistiksel olarak anlamlı bir ilişki vardır.

H8: Tepe yönetimin çalışanlara yönelik örgütsel motivasyon destekleri ile zincir mağazaların örgütsel güçlenmeleri arasında istatistiksel olarak anlamlı bir ilişki vardır. 


\subsection{Yöntem, Kapsam, Ölçek}

Araştırma kapsamında gereksinim duyulan veriler birincil veri niteliğindedir. Bu nedenle, birincil veri ihtiyacını karşılamada en fonksiyonel yöntem olan anket yöntemi tercih edilmiştir. Veri toplama süreci yüz yüze görüşmeler ile yürütülmüştür. Araştırmanın evreni; örgütsel yapı olarak ulusal ölçekte faaliyet gösteren bir franchise sistemi içinde zincir mağazalar/şubeler şeklinde yer alan işletmelerdir. Böyle bir zincirde; franchise veren ana işletme tepe yönetimini temsil etmekte olup, franchise alarak zincirin üyesi olan diğer işletmeler/şubeler ise tepe yönetimine bağlı faaliyet gösteren örgütsel birimler durumundadır.

Sözkonusu ana kütleyi temsilen seçilen örneklem Dominos Pizza Türkiye merkezine bağlı franchise şubelerdir. Bu örneklem özellikle seçilmiş olmayıp, bu çalışmanın yapılabilmesi için başvurulan çeşitli işletmeler arasından, anket talebimize olumlu cevap veren işletme olması nedeniyledir.

Anket formu aracılığı ile veri toplama sürecinde franchise şubelerin müdürleri veya sahipleri ile yüz yüze görüşülerek, çalışmanın tamamen akademik bir nitelik taşıdığı detaylı olarak anlatılmış ve çeşitli kaygılarla eksik yada yanlış bilgilerin verilmesi riski en aza indirilmiştir. 2021 yılı Ocak ayı boyunca Dominos Pizza Türkiye Merkezi desteği ile toplam 280 mağaza ile temas kurulmuş olup, bunlar arasında ankete katılmayı kabul eden 133 işletme bu çalışmanın örneklemini oluşturmuştur.

Araştırma modelindeki değişkenleri kapsayan 6 bölümden ve toplam 57 sorudan oluşan bir anket formu geliştirilmiştir. Ayrıca demografik bilgilere yönelik kısa bir bölüm eklenmiştir. Kriz Yönetimi Anlayışı değişkenini ölçmek amacıyla bir doktora tezi kapsamında Sayin (2008) tarafından geliştirilen "Kriz Yönetimi Ölçeği" ve Aslan, Küçükaltan ve Uzun (2020) tarafından geliştirilen “Kriz Yönetim Süreci Değerlendirme Ölçeği” kullanılmıştır. Bu ölçek kapsamında 14 ifade katılımcılara sunulmuştur.

Tepe yönetiminden franchise mağazalara yöneltilen Örgütsel İletişim (Öİ) değişkenini ölçmek amacıyla Miles, Patrick ve King (1996) tarafından geliştirilen “Örgütsel İletişim Ölçeği” esas alınmış ve orijinal ölçekteki bazı maddelerin bu çalışma ile örtüşmemesi nedeniyle 6 maddelik kısmı kullanılmıştır.

Bu çalışmada, tepe yönetiminin kriz yönetimi anlayışının mantıksal bir uzantısı olarak düşünülen ve "Süreç Reorganizasyonu" olarak isimlendirilen değişkeni ölçmek için Garvare ve Isaksson (2001) tarafından 12 kriter kullanılarak geliştirilen “Örgütlerin Sürdürülebilir Gelişmesi için Süreç Yönetimi" ölçeğinden yararlanılmıştır. 8 ifadeden oluşan bu ölçek, 
"reorganizasyon" konusunda tepe yönetimi tarafından ortaya konulan yaklaşımın franchise işletmeler tarafından algılanma biçimini ölçmeyi amaçlamaktadır.

Bu çalışmanın araştırma modelinde yer alan bir diğer değişken olan “Örgütsel Liderlik (ÖL)" değişkeni, tepe yönetiminin kriz ortamında ortaya koyduğu liderliğin ve "paylaşılan vizyon" becerisinin hangi düzeyde olduğunu, zincir mağazaların gözünden bakarak ölçmeye yöneliktir. Bu değişkeni ölçmeye yönelik olarak Laub (1999) tarafından geliştirilmiş olan "Örgütsel Liderlik Ölçeği" Kahveci ve Aypay'ın (2012) çalışmasından yararlanılarak kullanılmıştır. Bu değişkeni ölçebilmek amacıyla 7 ifade katılımcılara sunulmuştur.

Tepe yönetiminin sahip olduğu kriz yönetimi anlayışının bir uzantısı olarak örgüt çalışanlarına yönelik “Örgütsel Motivasyon” (ÖM) ölçeğini ölçmek için literatürde yaygın kabul gören "Minnesota Tatmin Ölçeği”nin (Weiss ve diğerleri, 1967) ilgili bölümünden yararlanılmıştır. ÖM ölçeğinde 9 ifade bulunmaktadır.

Bu çalışma bağlamında geliştirilen araştırma modelinde temel bağımlı değişken olarak yer alan "Örgütsel Güçlenme (ÖG)" değişkenini ölçmek için ise Kantur ve Say (2015) tarafından geliştirilen "Örgütsel Dayanıklılık (Organizational Resilience Scale)" ölçek kullanılmıştır. Bununla birlikte bu ölçekte yer alan tüm ifadeleri kullanmak yerine bu çalışma ile uyumlu olan 13 ifade tercih edilmiştir.

Anket formunda yer alan ve araştırma modelindeki 6 değişkeni temsil eden toplam 57 ifadenin tamamı 5 noktalı Likert ölçeği (Kesinlikle Katılıyorum / Kesinlikle Katılmıyorum) ile sunulmuştur. Bu araştırma için tasarlanan model; kriz koşullarında örgütsel güçlenmenin esas olarak, tepe yönetiminin kriz yönetimi anlayışının uzantısı olan uygulamaların bir fonksiyonu olduğu tezinden yola çıkmaktadır. Bu bağlamda, araştırma modeli çerçevesinde ilk aşamada; Örgütsel İletişim (Öİ), Örgütsel Liderlik (ÖL), Süreç Reorganizasyonu (SR) ve Örgütsel Motivasyon (ÖM) bağımlı değişken olarak incelenirken, ikinci aşamada ise sözkousu değişkenler bağımsız değişken gibi düşünülüp Örgütsel Güçlenme (ÖG) ise modeldeki nihai bağımlı değişken olarak ele alınmaktadır.

Araştırma kapsamında “Pandemi Sürecinde Kriz Yönetiminin İşlevselliğinin Zincir Mağaza Yönetimi Açısından Analizi: Bir Ulusal Zincirde Örgütsel Güçlenme Üzerindeki Yansımalar" başlıklı proje teklifi dosyası İstanbul Medeniyet Üniversitesi Sosyal ve Beşerî Bilimler Araştırma ve Yayın Etiği Kurulu'na sunulmuş, kurul tarafından dosya incelenerek, 19.03.2021 tarihinde 2021/17 sayılı projenin içeriğinde etik olarak bir sorun olmadığına ön koşulsuz olarak karar verilmiştir.

\subsection{Araştırmanın Kısıtları}


Bu çalışmanın sonuçları yorumlanırken dikkate alınması gereken iki önemli kısıt söz konusudur. Birincisi; çalışmada elde edilen veriler, katılımcıların gözünden bakılarak tepe yönetiminin kriz yönetimi anlayışı ve bu anlayış doğrultusunda yaptıklarının algılanmasına ilişkindir. Diğer bir ifadeyle, bu veriler örgüt üyeleri tarafından sağlanan veriler olup, tepe yönetiminin yaklaşımı, uygulamaları ve elde edilen sonuçları örgüt üyelerinin değerlendirme biçimleridir. Dolayısıyla, örgütün tepe yönetimine nasıl bir kriz yönetimi anlayışına, uygulamalara ve sonuçlara sahip oldukları sorulduğunda farklı verilere ulaşmak olasıdır. İkinci kısıt ise, çalışmadaki verilerin sadece Dominos Pizza Franchise zincirindeki işletmelerden toplanmış olması durumudur. Araştırma kapsamında yer alacak olan işletme sayısındaki artışa ve farklı zincir-örgütlerin de araştırmaya dahil edilmesine paralel olarak, sonuçların genelleştirilebilirlik düzeyi de artacaktır.

\section{VERILERIN ANALİZi VE BULGULAR}

\subsection{Demografik ve Tanımlayıcı Özellikler}

Tablo 1'de örneklemi oluşturan katılımcıların demografik özelliklerine ilişkin veriler sunulmaktadır.

Tablo 1: Demografik ve Tanımlayıcı Özellikler

Demografik Özellikler $\quad$ n $\quad \%$

$\begin{array}{llcc}\text { Cinsiyet } & \text { Kadın } & 41 & 30.8 \\ & \text { Erkek } & 92 & 69.1 \\ \text { Yaş } & 20-40 & 32 & 24.0 \\ & 41-60 & 55 & 41.3 \\ & 61 \text { ve üzeri } & 46 & 34.5 \\ & & & \\ \text { Eğitim Düzeyi } & \text { İlköğretim } & 23 & 17.2 \\ & \text { Lise } & 59 & 44.3 \\ & \text { Üniversite } & 34 & 25.5 \\ & \text { Lisansüstü } & 17 & 12.7 \\ \text { Pozisyon } & \text { İşletme Sahibi } & & 66.1 \\ & & & \\ & \text { Müdür } & 45 & 33.8\end{array}$


Çalışma Süresi

2 yıldan az

31

2- 4 yil

50

5 y1l ve üzeri
23.3

37.6

39.1

Tablo 1'te, örneklemi oluşturan katılımcıların demografik özelliklerine ilişkin verilerin analizi sunulmaktadır. Katılımcıların cinsiyet dağılımına bakıldığında, erkeklerin örneklem içindeki büyük grubu oluşturduğu ve cinsiyet dağılımında bir denge olmadığı görülmektedir. Katılımcılar yaş dağılımı açısından değerlendirildiğinde, en büyük grubu 41 - 60 yaş grubu oluşturmaktadır. Bununla birlikte 61 yaş ve üzeri olan gruptaki katılımcılar da ikinci büyük grubu oluşturmaktadırlar ki her iki grup bir arada ele alındığında toplam örneklemin \% 75.8 gibi büyük bir kısmını temsil etmektedirler. Bu veriye bakılarak, örneklemin ağırlıklı olarak orta yaş ve üzeri bir kitleden oluştuğunu söylemek mümkündür. Katılımcıların eğitim düzeyine bakıldığında ise en büyük grubun lise eğitimi aldığı (\% 44.3) fakat bununla birlikte üniversite eğitimi alan grubun da ikinci büyük grubu oluşturduğu görülmektedir. Bu istatistik, bu çalışmadaki verilerin kaynağı olan örneklemin göreceli olarak eğitimli bir kitleyi temsil ettiğini göstermektedir. Bu durum, araştırma kapsamında sorgulanan "kriz yönetimi anlayışı ve uygulamaları" gibi entellektüel düzeyi yüksek bir konuyu katılımcıların kavrayabileceği ve dolayısıyla da cevapların sıhhati konusunda olumlu bir sinyal olarak değerlendirilebilir.

Katılımcıların örgütteki pozisyonlarına bakıldığında büyük çoğunluğun işletme (franchise mağaza) sahibi olduğu anlaşılmaktadır. Örgütteki çalışma sürelerine bakıldığında ise uzun dönemden bu yana bu örgüt ile çalışıldığını söylemek mümkündür. Bu veri, bir önceki veri olan "örgütsel pozisyon" ile birlikte değerlendirildiğinde; franchise mağaza sahiplerinin uzun dönemden bu yana zincir üyesi mağaza oldukları anlaşılmaktadır. Bu durum, daha önce de ifade edildiği gibi bu çalışmada toplanan verilerin sıhhatini de arttırabilecek bir faktör niteliğindedir.

\subsection{Faktör Analizi ve Sonuçları}

$\mathrm{Bu}$ çalışma için tasarlanan araştırma modelinde yer alan değişkenleri ölçebilmek amacıyla, katılımcılara Likert ölçeğine göre düzenlenmiş toplam 57 ifade sunulmuştur. Bunlardan 14 tanesi “Tepe Yönetimin Kriz Yönetimi Anlayışı” (TYKYA)'na ilişkin ifadeler iken, 6 ifade “Örgütsel İletişim" (ÖI), 8 ifade 'Süreç Reorganizasyonu” (SR), 7 ifade "”Örgütsel Liderlik" (ÖL) ve 9 ifade de "Örgütsel Motivasyon" (ÖM) değişkenine yöneliktir. TYKYA, araştırma modelinin temel bağımsız değişkeni olup geniş bir aralıktaki ifadeleri içerdiğinden, sözkonusu değişkenin hangi temel boyutlardan oluştuğunu görebilmek için, bu ifadeler gruplarına Temel Bileşenler Faktör Analizi uygulanmıştır. 


\section{AJIT-e Bilişim Teknolojileri Online Dergisi \\ Academic Journal of Information Tecnology}

2021 Spring/Bahar - Cilt/Vol: 12 - Sayı/Issue: 45

doi) 10.5824/ajite.2021.02.007.x

Aynı yaklaşım bu çalışmanın araştırma modelinde nihai bağımlı değişken olan ÖG değişkeni için de geçerlidir. ÖG bağımlı değişkenini ölçebilmek için katılımcılara Likert Ölçeği formatında 13 ifade sunulmuştur. Faktör analizi; bir değişkeni ölçmek için geliştirilen ölçekteki alt birimlerin, kendi aralarındaki bağlılığı ve benzerliklerini incelemektedir (Yaşlığlu, 2017). Bunun yanısıra, sözkonusu analiz yoluyla elde edilen faktör değerlerinin, bu çalışmadaki asıl analiz durumundaki regresyon analizi için kullanılabilir olması gerekmektedir. Regresyon analizi yoluyla, bu çalışmadaki bağımsız değişkenlerin, “Örgütsel Güçlenme" (ÖG)'yi ne derece açıkladıklarını anlamak mümkün olacaktır.

Tablo 2 TYKYA ile ilgili ifadelere uygulanan faktör analizinin sonuçlarını göstermektedir. Buna göre, TYKYA'na ilişkin üç boyuttan söz etmek mümkündür. Birinci boyut, tepe yönetiminin kriz yada krizleri algılama gücü/yetisini ifade etmekte ve varyansın \% 34,2'sini açıklamaktadır. İkinci boyut, tepe yönetimin, algıladığı krize yönelik atikliğini ifade etmek olup tepki hızı olarak adlandırılmıştır. Bu boyut varyansın \% 25,1'ini açıklamaktadır. Üçüncü boyut ise tepe yönetimin sahip olduğu kriz yönetimi anlayışının "onarıcı" niteliğini vurgulamaktadır ve bu boyut tarafından açıklanan varyans \% 24.4'tür. Açıklanan toplam varyans \% 83,7 olarak ortaya çıkmakta ve ulaşılan sonuçlar boyutların güvenilirliğini göstermektedir (Hair ve diğ., 1998).

Tablo 2: Tepe Yönetimin Kriz Yönetimi Anlayışı (TYKYA)'na İlişkin Boyutlar

Faktörler

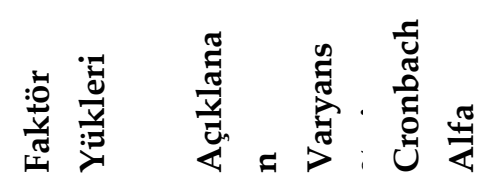

Faktör 1 : Algılama Gücü/Yetisi

34.2

0.802

Tepe yönetim; diş dünyada ne olursa olsun olduğu yerde , 861

durur ve pozisyonunu korur (T)

Tepe yönetim; son ana kadar krizleri görmezden gelir. (T) $\quad .808$

Tepe yönetim; kriz koşullarının yol açtı̆̆ı yeni rekabet ,729

gerekliliklerine çok duyarlıdır.

Tepe yönetim; kriz konularının abartıldığını düşünür. (T) ,611

Tepe yönetim dünyadaki ve ülkedeki problemleri anlamak , 519

için sürekli pazar araştırması yapar ve bizimle paylaşır.

Faktör 2: Tepki Hızı / Atiklik

25.1

0.720

Tepe yönetim; koşullar değiştiğinde hızlıca aksiyon alır. , 801 
Tepe yönetim; kriz durumlarında acil toplantılar ve değerlendirmeler yaparak, ihtiyaç duyduğumuz ,737 aksiyonları çok hızlı geliştirir.

Tepe yönetimi kriz koşulları için önceden alternatif ,619 planları hazırda tutar

\section{Faktör 3: Onarıcılık}

Tepe yönetim; olumsuz durumlarda farklı çözümler ,823 üretmede başarılıdır.

Tepe yönetim; kriz ortamlarında hangi çözümler ,728 geliştirilebileceğine dair özel çalışma grupları oluşturur.

Tepe yönetim; krizi yönetebilmek için alınacak önlemler konusunda franchise mağazalarla işbirliği yaparak fikirlerimize başvurur.

Tepe yönetim; kriz koşulları ve krizin boyutları konusunda etkili bilgilendirmeler yapar ve bilgi paylaşır

Tepe yönetim; kriz koşullarının çalışanlara olumsuz yansımalarını önlemek için çok duyarlıdır.

Tepe yönetim; kriz koşullarında, çalışan memnuniyetini korumak ve yükseltmeyi özellikle önemsediğini şirket kamuoyuna açıkça gösterir.

,702

,645

,613

, 522
24.4

0.709

Açıklanan Toplam Varyans

83.7

Kaiser - Meyer - Olkin (KMO) Değeri : 0.803 (varimax rotasyonu)

Tablo 3'te, bu araştırmadaki temel bağımlı değişken durumunda olan ÖG'nin hangi boyutlardan meydana geldiğini anlamaya yönelik olarak faktör analizinin sonuçları sunulmaktadır. Uygulanan Faktör Analizi sonucunda iki faktör boyutu gözlemlenmiştir. Bu faktörler toplam varyansın \% 76,3'ünü açılayıcı bir güce sahiptir. Sözkonusu iki faktör boyutu içerdiği ifadeler grubu dikkate alınarak; fiziki güçlenme ve beşeri güçlenme olarak adlandırılmıştır.

Tablo 3: Örgütsel Güçlenme (ÖG) Değişkenine İlişkin Boyutlar

Faktörler

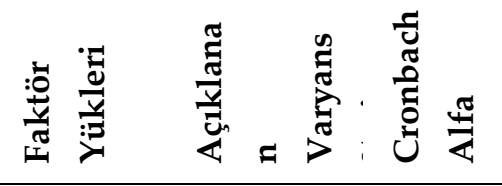

Faktör 1 : Fiziki Güçlenme

40.6

0.767 


\section{AJIT-e Bilişim Teknolojileri Online Dergisi \\ Academic Journal of Information Tecnology}

2021 Spring/Bahar - Cilt/Vol: 12 - Sayı/Issue: 45

doi) 10.5824/ajite.2021.02.007.x

Pandemi öncesine göre, daha iyi karar verme süreçlerine , 811 sahibiz.

Pandemi öncesine göre, daha iyi fiziksel koşullara sahibiz $\quad$.765

Pandemi öncesine göre, daha iyi örgüt içi iletişim ,701

kanallarına sahibiz

Pandemi öncesine göre, daha iyi müşteri iletişim ,641

süreçlerine sahibiz

Pandemi öncesine göre, tüm süreçlerde teknolojik ,539

iyileştirmelere sahibiz

Pandemi öncesine göre, yeni iletişim teknolojileri tüm

iletişim süreçlerine entegre edildi

Faktör 2: Beşerî Güçlenme

Pandemi öncesine göre, genel merkezden daha yoğun eğitim desteği alıyoruz , 774

Çalışan memnuniyetine ilişkin ölçümler; memnuniyetin üst düzeyde olduğunu göstermektedir.

Çalışanlarımıza başka şirketlerden daha iyi teklifler gelse ,630 bile bizimle çalışmaya devam ederler Çalışanlarımız; arkadaşlarına, şirketimizi çalışmak için ,604 tavsiye ederler.

Çalışanlarımız ortaya çıkan anlık problemlerde inisiyatif ,566 kullanma yetkisine sahiptirler

Çalışanlarımıza yıl boyunca kişisel gelişim eğitimleri ,551 verilir

Çalışanlarımıza yıl boyunca mesleki gelişim eğitimleri ,540 verilir

Açıklanan Toplam Varyans

76.3

Kaiser - Meyer - Olkin (KMO) Değeri : 0.768

Faktör analizleri sonucunda, araştırma modelinin temel bağımsız değişkeni (TYKYA) ile temel bağımlı değişkeni (ÖG)'nin alt boyutlarının netleşmesi ile birlikte araştırma modelinin nihai hali de aşağıdaki Şekil 2' de görüldüğü gibi şekillenmiştir. 


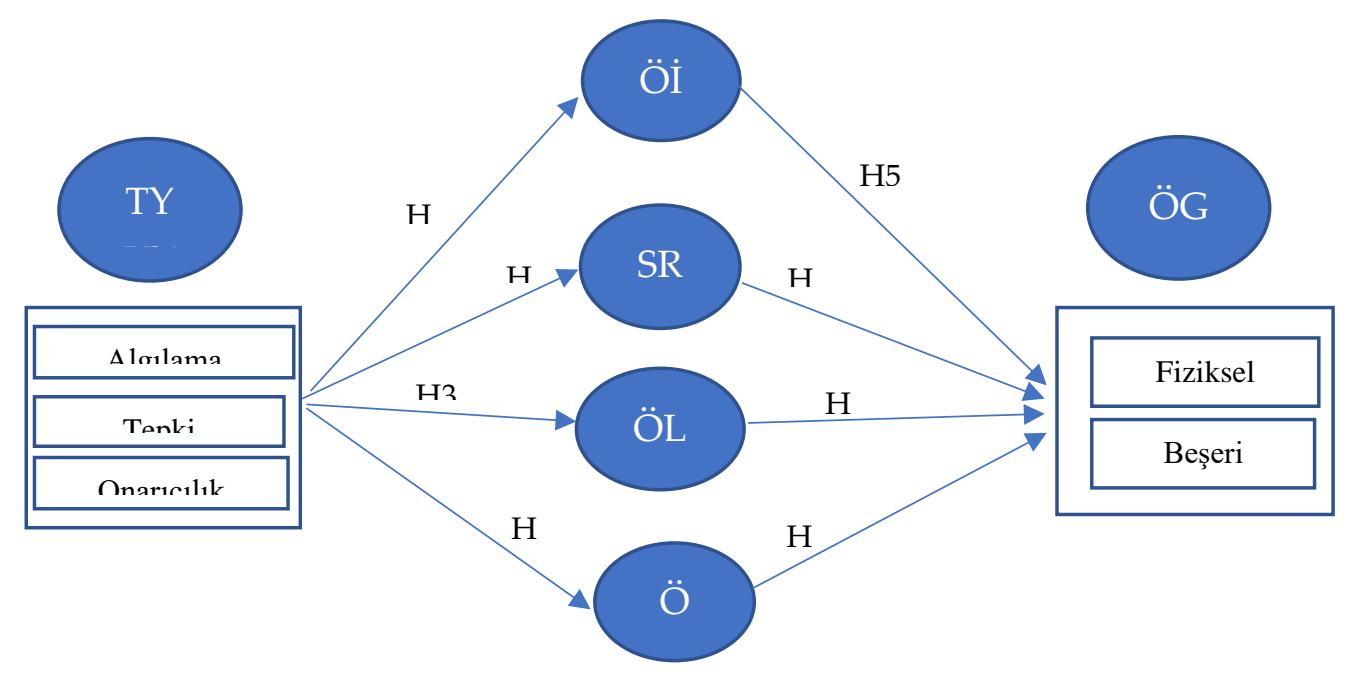

Şekil 2: Araştırma Modeli Nihai Görünümü

\subsection{Değişkenler Arası İlişkiler: Regresyon Analizi}

Daha önce de belirtildiği gibi bu çalışmanın temel amacl; işletmelerin tepe yönetimlerinin kriz yönetimi anlayışının (TYKYA) örgütsel süreçler ve sonuçlar üzerindeki somut etkilerini anlayabilmektir. Bu bağlamda ilk aşamada TYKYA ve ikinci aşamada da bu değişkenin uzantıları olan değişkenler "bağımlı değişken” olarak ele alınarak, şekil 2'de gösterilen model çerçevesinde çeşitli regresyon modelleri incelenmiştir. Bu amaçla yedi farklı regresyon modeli çalıştırılmıştır. Bu modellerden ilk dördü (Model 1, Model 2, Model 3 ve Model 4); Örgütsel İletişim (Öİ), Örgütsel Liderlik (ÖL), Süreç Reorganizasyonu (SR) ve Örgütsel Motivasyon (OM) ile TYKYA ile ilişkisini ve TYKYA'nın bu değişkenler üzerindeki belirleyiciliğini incelemektedir. Bundan sonraki modeller ise; Öİ, ÖL, SR ve OM değişkenlerinin modeldeki nihai bağımlı değişken olan Örgütsel Güçlenme (ÖG) üzerindeki etkisini ölçmeye yöneliktir. En son model olan model 7'de ise önceki modellerden elde edilen sonuçların bir anlamda sağlamasını yapmak amacıyla, ÖG değişkenindeki boyutların (fiziksel güçlenme - beşeri güçlenme) aritmetik ortalaması alınarak ÖG Genel Bağımlı Değişkeni kullanılarak ölçüm yapılmıştır.

Kurulan modeller ve analiz sonuçları şekil 3 ve tablo 4 'te gösterilmektedir. Bağımlı değişkenler, sırasıyla $\mathrm{y}_{1, \ldots \mathrm{y}}$ ve bağımsız değişkenler de faktör boyutları sırasıyla $\mathrm{x}_{1}, \mathrm{x}_{2}$ ve $\mathrm{x}_{3}$ olmak üzere, her bir modele ilişkin formül şu şekildedir:

Model 1 - Örgütsel İletişim (Öİ) ile Bağımsız Değişkenin Faktör Boyutları Arasındaki İlişki

$\mathrm{y}_{1}=\mathrm{a}+\beta_{1} \mathrm{x}_{1}+\beta_{2} \mathrm{x}_{2}+\beta_{3} \mathrm{x}_{3}$

Model 2 - Süreç Reorganizasyonu (SR) ile Bağımsız Değişkenin Faktör Boyutları Arasındaki İlişki 


\section{AJIT-e Bilişim Teknolojileri Online Dergisi \\ Academic Journal of Information Tecnology}

2021 Spring/Bahar - Cilt/Vol: 12 - Sayı/Issue: 45

doi) 10.5824/ajite.2021.02.007.x

$y_{2}=a+\beta_{1} x_{1}+\beta_{2} x_{2}+\beta_{3} x_{3}$

Mode1 3 - Örgütsel Liderlik (ÖL) ile Bağımsız Değişkenin Faktör Boyutları Arasındaki İlişki

$\mathrm{y}_{3}=\mathrm{a}+\beta_{1} \mathrm{x}_{1}+\beta_{2} \mathrm{x}_{2}+\beta_{3} \mathrm{x}_{3}$

Model 4 - Örgütsel Motivasyon (OM) ile Bağımsız Değişkenin Faktör Boyutları Arasındaki İlişki

$$
y_{4}=a+\beta_{1} x_{1}+\beta_{2} x_{2}+\beta_{3} x_{3}
$$

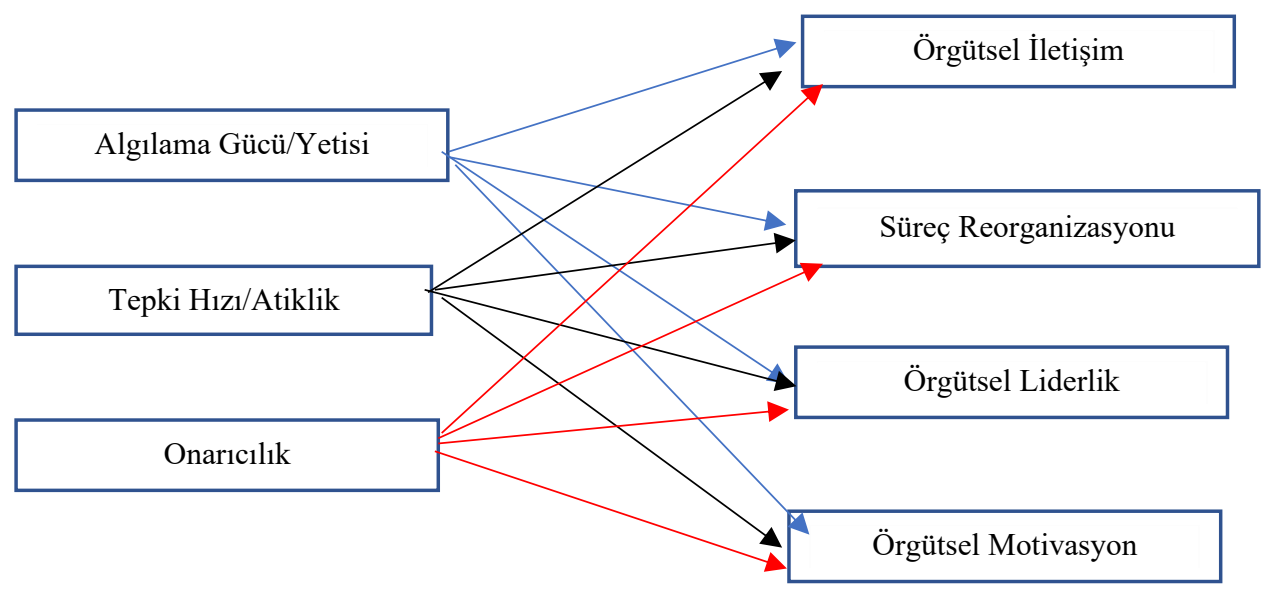

Şekil 3: Regresyon Modelleri - İlk Aşama

Kurulan regresyon modellerine ilişkin sonuçlar tablo 4 'te sunulmaktadır. Kurulan tüm modellerde F değerinin 0.01 anlamlılık düzeyinde geçerli olduğu görülmektedir. Sırasıyla, bağımlı değişkenler Örgütsel İletişim, Süreç Reorganizasyonu, Örgütsel Liderlik ve Örgütsel Motivasyon ile toplam üç bağımsız değişken analize tabi tutulmuştur.

Tablo 4: Bağımlı Değişkenler ile TYKYA'nın Faktör Boyutları Arasındaki Regresyon Analizi Sonuçları

Standartlaştırılmış $\quad$ t $\quad$ Anlamlılık
Katsayılar

\begin{tabular}{|c|c|c|c|c|}
\hline \multirow[t]{4}{*}{ Model 1} & $F: 71.287 *$ & Beta & & \\
\hline & Algılama Gücü/Yetisi & 631 & 8,502 &, 000 \\
\hline & Tepki Hızı/ Atiklik & 203 & 2,761 & ,007 \\
\hline & Onarıcılık & ,412 & 5,013 & ,000 \\
\hline
\end{tabular}


* 0.01 anlamlılık düzeyi ; Bağımlı Değişken: Örgütsel İletişim

\section{Model $2 \quad R^{2}: 0.704 \quad F: 93.110 *$}

$\begin{array}{lrrr}\text { Algılama Gücü/Yetisi } & , 710 & 10,101 & , 000 \\ \text { Tepki Hizl/ Atiklik } & , 386 & 4,185 & , 000 \\ \text { Onarıcılık } & , 501 & 5,443 & , 000\end{array}$

* 0.01 anlamlılık düzeyi ; Bağımlı Değişken: Süreç Reorganizasyonu

\begin{tabular}{|c|c|c|c|c|}
\hline \multirow[t]{4}{*}{ Model 3} & $R^{2}: 0.602$ & & & \\
\hline & Alg1lama Gücü/Yetisi & ,663 & 7,794 & , 000 \\
\hline & Tepki Hızı/ Atiklik & ,287 & 2,692 & ,004 \\
\hline & Onarıcılık & 611 & 6,844 & ,000 \\
\hline
\end{tabular}

* 0.01 anlamlılık düzeyi ; Bağımlı Değişken: Örgütsel Liderlik

Model $4 \quad R^{2}: 0.743 \quad$ F: $172.996 *$

$\begin{array}{lccc}\text { Algılama Gücü/Yetisi } & , 401 & 8,836 & , 000 \\ \text { Tepki Hızı/ Atiklik } & , 313 & 5,120 & , 000 \\ \text { Onarıcılık } & , 577 & 10,205 & , 000\end{array}$

* 0.01 anlamlılık düzeyi ; Bağımlı Değişken: Örgütsel Motivasyon

Model 1'de F değerinin 71.287'nin 0.01 anlamlılık düzeyinde geçerli olduğu görülmektedir (Tablo 4). Bağımlı değişken olan Örgütsel İletişim ile toplam üç bağımsız değişken analize tabi tutulmuştur. Analiz sonucuna göre, bağımsız değişkenler Örgütsel İletişim'deki değişimin \% 62.7'sini açılamaktadır (Model 1). Örgütsel İletişim değişkenini açıklayan en önemli faktör Algılama Gücü/Yetisi'dir. Diğer bir ifadeyle tepe yönetimin kriz durumunu algılama becerisi ve bu konudaki algısal duyarlılı̆̆ı arttıkça örgütsel iletişime 


\section{AJIT-e Bilişim Teknolojileri Online Dergisi \\ Academic Journal of Information Tecnology}

2021 Spring/Bahar - Cilt/Vol: 12 - Sayı/Issue: 45

doi) 10.5824/ajite.2021.02.007.x

odaklanma düzeyleri de artmaktadır. Bunun yanısıra, Onarıcı nitelikteki kriz yönetimi anlayışı da örgütsel iletişimi arttıran ikinci önemli faktör olarak gözlemlenmiştir ( $t: 5.013$; p: 0.000). Tepe yönetimin kriz yönetimi anlayışında Onarıcı nitelik baskın oldukça örgütsel iletişimde de iyileşme görülmektedir.

Model 2'de tepe yönetimin Süreç Reorganizasyonu faaliyetleri ile TYKYA arasındaki ilişkiye dair analiz sonuçları sunulmaktadır. Buna göre, F: 93.110 ve $p$ değeri 0.00 olduğundan model anlamlıdır. TYKYA'nı oluşturan üç faktör boyutunun Süreç Reorganizasyonu faaliyetlerini açılama kabiliyeti \% 70.4'tür. Model 2'deki sonuçlara göre, bağımlı değişkeni açıklayan en önemli faktör tepe yönetiminin krizi Algılama Gücü/Yetisi'dir. Örgütsel süreçlerin reorganizasyonundaki artışlar yada azalışlarda (yoğunlaşmalarda yada önemsiz görmelerde) tepe yönetimin krizi algılama gücü / yetisi belirleyici olmaktadır. Öte yandan, bir diğer bağımsız değişken olan Onarıcılık değişkeni de Süreç Reorganizasyonu faaliyetleri üzerinde bir diğer güçlü belirleyici olarak öne çıkmaktadır ( $t: 5.443$; p: 0.000). Denilebilir ki tepe yönetimin Onarıcı yönlü kriz yönetimi anlayışı örgütsel süreçlerin reorganizasyonu faaliyetlerine önem verilmesine neden olmaktadır.

Kriz koşullarında Örgütsel Liderlĭgin ortaya çıkmasında yada belirgin olmasında TYKYA'nın belirleyiciliğini görebilmek için Model 3'te sunulan regresyon modeli kurulmuştur. Model 3'te F:66.784 ve p: 0.00 olduğu için model anlamlıdır. Bağımlı değişken olarak Örgütsel Liderlik ile üç bağımsız değişkenin ilişkisine bakıldığında, TYKYA'nı temsil eden her üç bağımsız değişkenin de Örgütsel Liderlik üzerinde belirleyici olduğu görülmektedir. Bununla birlikte, daha önceki Model 1 ve Model 2 ile benzerlik gösterecek şekilde, Örgütsel Liderlik üzerindeki en önemli katkı Algılama Gücü/Yetisi (t:7.794; p:0.000) ve Onarıcılık (t: 6.844; p:0.000) boyutlarından gelmektedir. Diğer bir ifade ile, tepe yönetimin krizi algılama gücü yada duyarlılığı arttıkça kriz koşullarında ortaya koyduğu örgütsel liderlik davranışları da belirginleşmektedir. Buradan hareketle denilebilir ki, kriz koşullarında örgütsel liderliğin belirginlikten uzak olması yada örgütsel yaşamda etkili bir faktör olarak gözlemlenmeyişi gibi durumlar aslında tepe yönetiminin krizi algılama becerilerinin düşük olmasından kaynaklanmaktadır. Sözkonusu beceri arttıkça, diğer bir ifadeyle dış çevre faktörlerindeki değişimleri okuyabilme becerisi geliştikçe kriz koşullarında ortaya konulacak olan liderlik de etkili ve belirgin olacaktır.

Model 4, kriz koşullarında tepe yönetimin ortaya koyduğu Örgütsel Motivasyon faaliyetleri ile TYKYA arasındaki ilişkiyi analiz eden regresyon modelidir. Bu model de F: 172.996 ve p: 0.00 anlamlılık düzeyinde geçerlidir. Modelde yer alan bağımsız değişkenlerin Örgütsel Motivasyon bağımlı değişkenini açıklama oranı \% 74.3 olup, bu oran daha önceki modellerdeki açıklayıcılık oranından daha yüksek bir düzeye işaret etmektedir. Örgütsel Motivasyon değişkeni üzerindeki en büyük katkının Onarıcılık boyutundan geldiği 
görülmektedir (t: 10.205; p:0.000). Dolayısıyla, tepe yönetimin “onarıcı" odaklı olarak kriz yönetimi anlayışına sahipliği örgüt boyunca motivasyon faaliyetlerinin ortaya çıkmasında yada belirginleşmesinde belirleyici bir faktördür. Bunun yanısıra, örgütsel motivasyon faaliyetleri üzerinde belirleyici olan bir diğer güçlü faktör de tepe yönetimin krizi Algılama Gücü/Yetisi'dir (t: 8.836; p:0.000). Tepe yönetimin krizi algılama gücü - becerisi arttıkça örgütsel motivasyon faaliyetleri de belirginlik kazanmaktadır. Bu durum, kriz koşullarında bazı örgütlerde motivasyon faaliyetlerinin neden belirgin olarak gözlemlenemediğini, bunun tersine olacak şekilde bazı örgütlerde de neden çok belirgin bir hal alabildiğini de açıklamaktadır.

Regresyon analizlerinin yukarıda açıklanan birinci aşamasından sonra, ikinci aşamasında ise iki ayrı regresyon modeli test edilmiştir. Bu modellerde Örgütsel Güçlenme (ÖG) temel bağımlı değişken olarak yer alırken modeldeki diğer değişkenler olan Öİ, SR, ÖL, ÖM ise bağımsız değişkenler olarak yer almaktadır (Şekil 4).

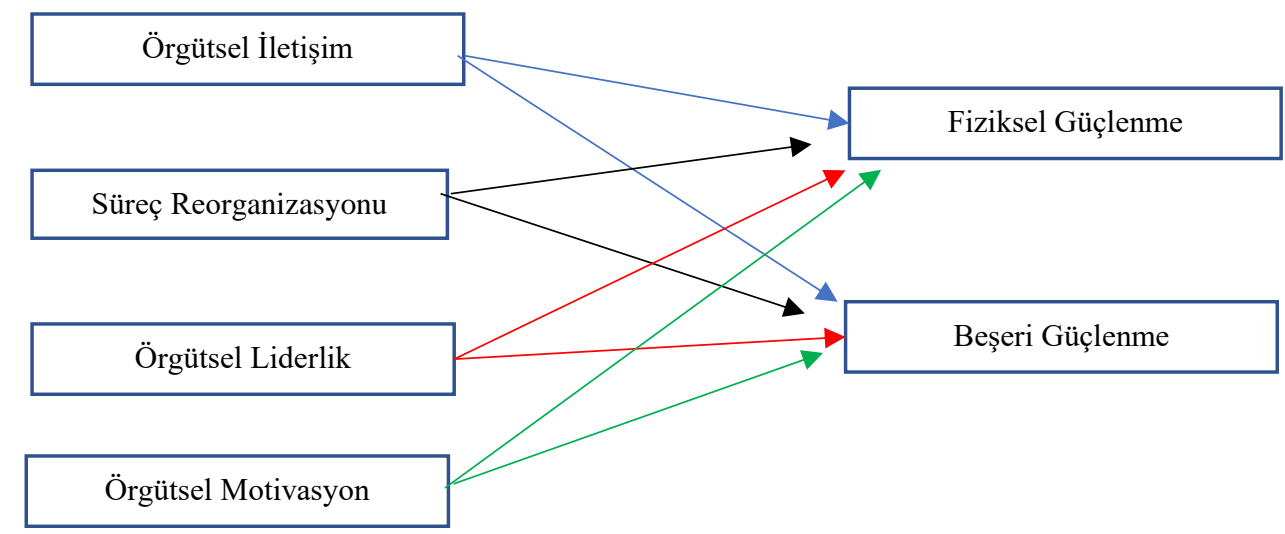

Şekil 4: Regresyon Modelleri - İkinci Aşama

Tablo 5, ikinci aşamada yapılan regresyon analizlerinin sonuçlarını göstermektedir. Model 5'teki skorlar incelendiğinde F: 83.631 ve p:0.00 olduğu için model anlamlıdır. Örgütsel Güçlenmenin alt boyutlarından biri olan Fiziksel Güçlenme ve bağımsız değişkenlerle birlikte modeli çalıştırdığımızda tüm bağımsız değişkenlerin Fiziksel Güçlenme üzerinde belirleyici olduğu görülmektedir. Bunlar arasında özellikle Örgütsel İletişim (t: 8.502; p:0.000) ve Süreç Reorganizasyonu (t: 7.910; p:0.000) faktörlerinin Fiziksel Güçlenme üzerinde daha belirgin bir etki yaptığını ifade etmek mümkündür. Buradan hareketle, kriz gibi olağanüstü ve sıkıntılı koşullarda örgütsel süreçlerin yeniden gözden geçirilerek iyileştirilmesi faaliyetleri ve tepe yönetiminden tüm örgüte yöneltilen iletişim faaliyetlerinin yoğunluğu örgütün fiziksel güçlenmesi üzerinde belirleyici olmaktadır. Diğer bir ifadeyle, örgütün fiziksel güçlenmesi için bir yandan reorganizasyon faaliyetleri yapılırken diğer yandan da örgütsel iletişim konusuna tepe yönetimi tarafından ağırlık verilmesi gerektiği ortaya çıkmaktadır.

Model 6' da ise bağımlı değişken olarak örgütsel güçlenmenin bir diğer alt boyutu olan Beşerî Güçlenme değişkeni modele alınarak analiz yenilenmiştir. Bu model için temel 


\section{AJIT-e Bilişim Teknolojileri Online Dergisi \\ Academic Journal of Information Tecnology}

2021 Spring/Bahar - Cilt/Vol: 12 - Sayı/Issue: 45

doi) 10.5824/ajite.2021.02.007.x

göstergeler olan F: 77.003 ve p: 0.00 modelin anlamlı olduğunu göstermektedir. Tablo 5'te sunulan sonuçlara bakıldığında özellikle Örgütsel Motivasyon ve Örgütsel İletişim faaliyetlerinin beşerî güçlenme üzerinde çok etkili olduğu anlaşılmaktadır. Bunların hemen ardından da Örgütsel Liderlik yine güçlü bir belirleyici olarak fonksiyon görmektedir. Süreç Reorganizasyonu ise beşerî güçlenme üzerinde belirleyici olmakla birlikte diğer faktörler kadar katkı sunmamaktadır. Model 6 göstermektedir ki örgüt boyunca çalışanların güçlendirilmesini ifade eden Beşeri Güçlenme'nin ortaya çıkarılabilmesi için öncelikle tepe yönetimin örgütsel motivasyon faaliyetlerine ve örgütsel iletişimin etkin ve başarılı bir şekilde yürütülmesine ihtiyaç bulunmaktadır.

Tablo 5: Örgütsel Güçlenme (ÖG) Boyutları ile Bağımsız Değişkenler Arasındaki Regresyon Analizi Sonuçları - İkinci Aşama

\begin{tabular}{|c|c|c|c|c|}
\hline & & $\begin{array}{l}\text { Standartlaştırılmış } \\
\text { Katsayılar }\end{array}$ & $\mathbf{t}$ & Anlamlılık \\
\hline \multirow[t]{5}{*}{ Model 5} & $R^{2}: 0.762 \quad F:$ :83.631* & Beta & & \\
\hline & Örgütsel İletişim & ,431 & 8,502 &, 000 \\
\hline & Süreç Reorganizasyonu &, 703 & 7,910 & ,000 \\
\hline & Örgütsel Liderlik & ,612 & 6,021 &, 000 \\
\hline & Örgütsel Motivasyon &, 544 & 4,485 & ,000 \\
\hline
\end{tabular}

* 0.01 anlamlılık düzeyi ; Bağımlı Değişken: Fiziksel Güçlenme

Model $6 \quad R^{2}: 0.729 \quad$ F: $\mathbf{7 7 . 0 0 3 *}$

$\begin{array}{lccc}\text { Örgütsel İletişim } & , 809 & 9,222 & \mathbf{, 0 0 0} \\ \text { Sürec Reorganizasyonu } & , 213 & 2,092 & \mathbf{, 0 0 5} \\ \text { Örgütsel Liderlik } & , 620 & 6,879 & \mathbf{, 0 0 0} \\ & , 816 & 10,131 & \mathbf{, 0 0 0}\end{array}$

* 0.01 anlamlılık düzeyi; Bağımlı Değişken: Beşeri Güçlenme

Model 5 ve Model 6'da uygulanan regresyon analizlerinin Örgütsel Güçlenme'yi bir bütün olarak aldığımızda nasıl sonuç vereceğini incelemek ve bir anlamda Model 5 ve 6'nın sağlamasını yapmak amacıyla üçüncü bir model kurulmasına karar verilmiştir. Bu modelin 
bağımlı değişkeni, Örgütsel Güçlenme (ÖG) değişkeninin faktör analizindeki boyutlarının (fiziksel - beşeri) aritmetik ortalaması ile belirlenmiştir. Böylece bu yeni bağımlı değişken Bütünsel Olarak Örgütsel Güçlenme (BOÖG) olarak tanımlanmıştır.

Bağımsız değişkenler ile yeni tanımlanan bağımlı değişken arasındaki ilişkiyi incelemek üzere aşağıdaki regresyon modeli kurulmuş ve analiz edilmiştir. Elde edilen sonuçlar tablo 6' da sunulmaktadir.

Model 7 -BOÖG ile bağımsız değişkenler arasındaki ilişki

$$
\mathrm{y}_{7}=\mathrm{a}+\beta_{1} \mathrm{x}_{1}+\beta_{2} \mathrm{x}_{2}+\beta_{3} \mathrm{x}_{3}+\beta_{4} \mathrm{x}_{4}
$$

Tablo 6: BOÖG ile Bağımsız Değişkenler Arasındaki Regresyon Analizi Sonuçları

\begin{tabular}{|c|c|c|c|c|}
\hline & & $\begin{array}{l}\text { Standartlaştırılmış } \\
\text { Katsayılar }\end{array}$ & $\mathbf{t}$ & Anlamlılık \\
\hline \multirow[t]{5}{*}{ Model 7} & $\mathrm{~F}: 179.586 *$ & Beta & & \\
\hline & Örgütsel İletişim &, 782 & 9,106 &, 000 \\
\hline & Süreç Reorganizasyonu & ,623 & 7,111 &, 000 \\
\hline & Örgütsel Liderlik &, 471 & 3,209 &, 000 \\
\hline & Örgütsel Motivasyon & ,698 & 7.874 &, 000 \\
\hline
\end{tabular}

Tablo 6'da sonuçları gösterilen son regresyon modeli; F: 179.586 ve p:0.00 anlamlılık düzeyinde geçerlidir. Modelde yer alan bağımsız değişkenlerin Bütünsel Olarak Örgütsel Güçlenme $(B O O ̈ G)$ bağımlı değişkenini açıklama oranı \% 79.5 olup, bu oran oldukça tatmin edici olarak ifade edilebilir. BOÖG üzerindeki en büyük katkının Örgütsel İletişim (t: 9.106; p:0.000) ve Örgütsel Motivasyon (t: 7.874; p: 0.000) faktörlerinden geldiği görülmektedir. Dolayısıyla, Model 7'nin ortaya koyduğu sonuçlar; kriz koşullarında yada krize benzeyen yüksek düzeyde sıkıntılı dönemlerde örgütsel güçlenmeyi gerçekleştirebilmek için öncelikle tepe yönetiminin örgütsel iletişim ve örgütsel motivasyon alanlarında ortaya koyduğu performansa bakılması gerektiğine işaret etmektedir. Bu sonuçlara dayanarak denilebilir ki; örgüt tepe yönetiminin sözkonusu alanlardaki başarı yada başarısızlığı Örgütsel Güçlenme sonucunu da olumlu yada olumsuz yönde belirleyecektir.

\section{GENEL DEĞERLENDİRME VE SONUÇ}




\section{AJIT-e Bilişim Teknolojileri Online Dergisi \\ Academic Journal of Information Tecnology \\ 2021 Spring/Bahar - Cilt/Vol: 12 - Sayı/Issue: 45 \\ doi) 10.5824/ajite.2021.02.007.x}

Kriz kavramı işletme biliminde ele alınan temel değişkenlerden birini temsil etmektedir. Kontrol edilemeyen diş çevre faktörlerinden kaynaklanacak zararlardan korunmak ancak bu faktörlere yönelik yaklaşımlar geliştirmek ve planlamalar yapmakla mümkündür. Krizlerin uzun bir zaman sürecine yayılması, derinleşmesi ve zamanla çevresel faktörleri tamamen kuşatması sonucunda kriz koşulları ortaya çıkmaktadır. Kriz koşullarında örgütlerin yapısal sağlığının korunması ve örgütsel performansın olumsuz bir noktaya gelmemesi, örgütün krizi nasıl yönettiği ile yakından ilişkilidir. Bu bağlamda kriz yönetimine yönelik anlayışlar ve beceriler önem kazanmaktadır.

Bu çalışma, dünyanın global ölçekte II. Dünya Savaşından bu yana gördügü en büyük kriz olan Pandemi koşullarında kriz yönetimi anlayışı ile örgütsel güçlenme arasındaki ilişkiyi incelemektedir. Diğer bir ifadeyle, örgütün tepe yönetiminin kriz yönetimine yaklaşım biçiminin örgüt-içi süreçler yoluyla örgütsel güçlenme üzerinde belirleyici bir faktör olup olmadığı sorusuna cevap aranmıştır. Araştırma sonucunda elde edilen bulgular; tepe yönetimin kriz yönetimi anlayışının örgütsel iletişim, örgütsel liderlik, örgütsel motivasyon ve reorganizasyon faaliyetlerini doğrudan ve önemli ölçüde belirlediğini ortaya koymaktadır. Bunun devamı niteliğinde ise sözkonusu değişkenlerin örgütsel güçlenme üzerinde güçlü bir belirleyici olduğu görülmüştür. Pandemi süreci gibi güçlü ve derin kriz koşullarında örgütün sağlığının korunması anlamına gelen örgütsel güçlenme; doğrudan doğruya tepe yönetimin krizi ele alma biçiminden, krizi yönetme konusundaki yaklaşımlarından kaynaklanan bir sonuç olmaktadır. Bu bağlamda, istenilen sonucu elde etmek için bu sonuç üzerinde etkili olan belirleyicileri ele almak prensibinden hareketle denilebilir ki örgüt tepe yönetimlerinin kriz yönetimi anlayışları iyileştirildiğinde yada güçlendirildiğinde bunun bir uzantısı olarak örgütsel güçlenme sonucuna ulaşmak mümkün olacaktır.

\section{KAYNAKÇA}

Amabil, T.M. ve Kramer, S.J. (2007). Inner work life: Understanding the Subtext of Business Performance. Harvard Business Review, 85 (5), $72-83$

Bass, B. M. (1990). Bass and Stodgill's Handbook of Leadership: Theory, Research and Managerial Applications, Free Press, USA.

Baubion, C. (2013). OECD Risk Management: Strategic Crisis Management.

Bushe, G. R. ve Marshak, R. J. (2009). Revisioning Organisation Development: Diagnostic and Dialogic Premises and Patterns of Practice. Journal of Applied Behavioral Science, 45(3), 112-127.

Chapman J.A. (2002). A framework for transformational change in organisations. Leadership and Organisation Development Journal, 23(1), 16-25.

Çağlar, İ. (2005), Türk İşletmeciliğinde Değişim ve Değişimin Yönetimi, Ankara: Gazi Kitabevi. 
Darling, J. R. (1994). Crisis Management in International Business: Keys to Effective Decision Making. Leadership \& Organization Development Journal, 15(8), 3-8

Dinçer, Ö. (1998). Stratejik Yönetim ve İşletme Politikası, Beta Basım Yayım Dağıtım, İstanbul.

Drath, W. H. ve Palus, C. J (1994). Making Common Sense: Leadership as Meaning-making in a Community of Practice. Greensboro, NC: Center for Creative Leadership.

Farhoodi, F. ve Babalhavaeji, F. (2015). Local Model of Crisis Management in Libraries of Iran's Research Centers (mixed research). Library Philosophy and Practice (e-journal). http://digitalcommons.unl.edu/libphilprac

Frone, M. and Major, B. (1998). Communication Quality and Job Satisafaction Among Managerial Nurses. Group \& Organization Studies, 13(3), p. 332-347

Garvare, R. (2002). Process Management and Sustainable Development in a Qauality Perspective. Doktora Tezi, Luleå University of Technology, İsveç.

Garvare, R. ve Isaksson, R. (2001). Sustainable Development: Extending The Scope of Business Excellence Models. Measuring Business Excellence, v: 5 (3), s: 11 - 15.

Gürgen H. (1997). Örgütlerde iletişim kalitesi, İstanbul, Der Yayınları.

Hosseini, Y. and et al (2013). The effect of strategic management on the quality of crisis management operations. Journal of Crisis Management. 2: 78-88.

Kahn, W. ve Barton, M.A. (2013). Organizational Crises and the Disturbance of Relational Systems. The Academy of Management Review, 38(3):377-396

Kahveci,H. ve Aypay, A. (2012). Hizmetkar Örgütlerde Örgütsel Liderlik Değerlendirme Ölçeği: Türk Kültürüne Uyarlama, Dil Geçerliliği ve Faktör Yapısının İncelenmesi. Eskişehir Osmangazi Üniversitesi SBE Dergisi, 13 (1), 19 - 42.

Kantur, D. ve Say, A. (2015). Measuring Organizational Resilience: A Scale Development. Journal of Business, Economics and Finance, v: 4(3), $456-472$.

Karcıoğlu, F., Timuroğlu, K. ve Çınar, O. (2009). Örgütsel İletişim ve İş Tatmini İlişkisi - Bir Uygulama. İstanbul Üniversitesi Yönetim Dergisi, 20(63), s. 59-76

Kreitner R. ve Kinicki A. (2003). Organisational Behaviour, 6th ed., McGraw-Hill/ Irwin, Boston, MA.

Laub, J. A. (1999). Assesing the Servant Organization : Development of the Organizational Leadership Assesment (ola) Instrument. Yayımlanmamış doktora tezi, University of Nebraska, Florida.

Lee, M. ve Raschke, R. L. (2016). Understanding employee motivation and organizational performance: Arguments for a Set-theoretic Approach. Journal of Innovation and Knowledge, 1 (3), $162-169$ 


\section{AJIT-e Bilişim Teknolojileri Online Dergisi \\ Academic Journal of Information Tecnology \\ 2021 Spring/Bahar - Cilt/Vol: 12 - Sayı/Issue: 45 \\ doi) 10.5824/ajite.2021.02.007.x}

Madan, S. (2017). Moving From Employee Satisfaction To Employee Engagement, International Journal of Research in Commerce \& Management, 8(6).

Myer, R. A., Conte, Christian. and Peterson, S. E. (2007). Human Impact Issues for Crisis Management in Organizations. Disaster Prevention and Management. 16( 5): 761-770.

Okumuş, F. (2003). İşletmelerde Kriz Yönetimi ve Krizlerin İşletmeler Üzerine Olası Etkileri. Atatürk Üniversitesi İ̈B Dergisi, 17(1-2), 203-212

Onay, M. ve Ergüden, S. (2011). Örgütsel-Yönetsel Motivasyon Faktörlerinin Çalışanların Performans Ve Verimliliğine Etkilerini İncelemeye Yönelik Ampirik Bir Çalışma: Manisa - Sosyal Güvenlik Kurumu. Organizasyon ve Yönetim Bilimleri Dergisi, 3 (2), 221 - 230

Örücü, E. Ve Kanbur, A. (2008). Örgütsel-Yönetsel Motivasyon Faktörlerinin Çalışanların Performans ve Verimliliğine Etkilerini İncelemeye Yönelik Ampirik Bir Çalışma: Hizmet ve Endüstri İşletmesi Örneği. Yönetim ve Ekonomi Dergisi, 15 (1), 85 - 97

Penrose, J. M. (2000). The Role of Perception in Crisis Planning. Public Relations Review, 26(2), 155-171

Pira, A. ve Kocabaş, F. (2003). Örgütsel İletişim Açısından Değişim Mühendisliğii. Kocaeli Üniversitesi Sosyal Bilimler Enstitüsü Dergisi, 5/1, 87-102.

Rad, A. and Moraes, A. (2009). Factors Affecting Employees' Job Satisfaction in Public Hospitals. Journal of General Management, 34(4), p. 51-66

Robbins S.P., De Cenzo D. ve Coulter M. (2014). Fundamentals of Management, Global Edition, Pearson Education Limited.

Rožman, M., Treven, S., \& Čančer, V. (2017). Motivation and Satisfaction of Employees in the Workplace. Business Systems Research: International Journal of the Society for Advancing Innovation and Research in Economy, 8(2), 14-25.

Sabuncuoğlu, Z. ve Tüz, M. (2005). Örgütsel Psikoloji. Bursa: Alfa/Aktuel Kitabevi.

Senior B. (2002) Organisational Change. Prentice Hall, London.

Starosta, A. (2014). Anti-crisis Management Strategies. The case of companies in the Greater Poland. Management, 18(1), 255-266

Tanrıverdi, H. ve Oktay, K. (2001). Otel İşletmelerinde İşgören Motivasyonuna Yönelik Bir Araştırma. Gazi Üniversitesi Vakfı Turizm Akademik, Sayı:2, 33-41.

Taşlıyan, M. ve Hırlak, B. (2014). Örgütsel İletişim Etkinliği ile İş Tatmini, Örgütsel Bağlılık, Örgütsel Vatandaşlık Davranışı Arasındaki İlişkilerin Araştırılması: Akademik Örgütler İçin Bir Alan Araştırması. Ekonomi ve Yönetim Araştırmaları Dergisi, 3(2), s. 7-36

Trent, R. F. (2004). Team Leadership at the 100-Foot Level. Team Performance Management, 10/5-6, 94103. 
Tüz, M. V. (2004). Kriz Yönetimi. Alfa Yayınları, İstanbul.

Yılmaz, B. (2003). Toplumsal İletişim ve Kütüphane. Hacettepe Ü. Edebiyat Fakültesi Dergisi, 20(2), s. 1129

Yaşlıoğlu, M. M. (2017). Sosyal Bilimlerde Faktör Analizi ve Geçerlilik: Keşfedici ve Doğrulayıcı Faktör Analizlerinin Kullanılması. İstanbul Üniversitesi İşletme Fakültesi Dergisi, C: 46, Özel Sayı, $74-85$

Yüksel, A. H. (2016). İletişim Süreci ve Sistem Yaklaşımı Açısından İletişim Sürecinin İncelenmesi. Kurgu, Anadolu Üniversitesi İletişim Bilimleri Fakültesi Dergisi, 6 (6), 15 - 63

Zoogah D.B. ve Beugré C.D. (2012). Managing Organizational Behaviour in the African Context, Routledge, New York. 